\title{
Assessment of developmental changes in chicken and turkey insulin-like growth factor-II by homologous radioimmunoassay
}

\author{
J P McMurtry, R W Rosebrough, D M Brocht, G L Francis', \\ Z Upton ${ }^{1}$ and $\mathbf{P}$ Phelps ${ }^{2}$
}

United States Department of Agriculture, Growth Biology Laboratory, Agricultural Research Service, Beltsville, Maryland 20705, USA, ${ }^{1}$ Cooperative Research Centre for Tissue Growth and Repair and CSIRO, Division of Human Nutrition, Adelaide, South Australia 5000, Australia and ${ }^{2}$ Embrex, Inc.,

PO Box 13989, Research Triangle Park, North Carolina 27709, USA

(Requests for offprints should be addressed to J P McMurtry)

\begin{abstract}
The development of a homologous RIA for chicken insulin-like growth factor-II (cIGF-II) and its application to investigate the developmental changes in IGF-II in the chicken and turkey are described. A double-antibody RIA has been developed using recombinantly derived cIGF-II as antigen, radiolabelled tracer and standard. Serial dilutions of chicken and turkey plasma were parallel to serial dilutions of cIGF-II standard. We have also established that acid/ethanol extraction of chicken and turkey plasma reduced possible interference of insulin-like growth factor-binding proteins in the RIA. Consumption of a low-protein diet by male chickens lowered plasma IGF-I twofold, whereas IGF-II levels were unchanged. Food withdrawal evoked an increase in circulating IGF-II,
\end{abstract}

while IGF-I levels were reduced. Refeeding returned both growth factors to normal circulating concentrations. During chick embryo incubation, plasma IGF-II levels were tenfold higher than those of IGF-I. In the turkey embryo, plasma IGF-II concentrations were higher than those of IGF-I. During the post-hatch period, IGF-II levels declined with age in chickens. In the growing turkey, IGF-II levels were consistently higher than IGF-I levels. The application of the homologous RIA to monitor plasma levels during embryonic development and posthatch growth in avian species will provide more accurate comparisons of results from studies on the role of IGF-II in growth and metabolism of domestic birds.

Journal of Endocrinology (1998) 157, 463-473

\section{Introduction}

The insulin-like growth factors (IGF-I and -II) are structurally related proteins with multiple effects on growth, development and metabolism in mammals (Rotwein 1991, Jones \& Clemmons 1995) and birds (McMurtry et al. 1997). More is known about the function of these multifunctional proteins in mammals than in avian species. Chicken IGF-I (cIGF-I) is more closely related to its mammalian counterpart in terms of amino acid sequence (Ballard et al. 1990) than is chicken IGF-II (cIGF-II) (Upton et al. 1995). Moreover, cIGF-II differs in 12 amino acids from human IGF-II. Whether these sequence differences are significant for biological function, including metabolism, is not known. Previously, we reported the development of a homologous RIA for cIGF-I and its application to further the understanding of the role of cIGF-I in growth and metabolism in chickens and turkeys (McMurtry et al. 1994, 1996a, b). IGF-II is a key regulator of fetal development in mammals (Stewart \& Rotwein 1996). Virtually nothing is known about the role of IGF-II during avian embryonic development and post-hatch growth. This situation is made more intriguing by the absence of an IGF-II-binding site on the chicken cationindependent mannose 6-phosphate receptor as exists for the mammalian receptor (Zhou et al. 1995). Prior estimates of circulating IGF-II in chickens have utilized a monoclonal antibody raised against human IGF-II and mammalian IGF-II as standard and tracer (Buonomo 1989, Huybrechts et al. 1989, Scanes et al. 1989, Kita et al. 1996). In this paper, we describe the development of a homologous RIA for cIGF-II and its application to the investigation of developmental changes in IGF-II in the chicken and turkey. This is the first report of a homologous RIA for avian IGF-II.

\section{Materials and Methods}

\section{Materials}

Recombinant cIGF-II, human IGF-II and cIGF-I were purchased from GROPEP Pty, Ltd, Adelaide, Australia. Chicken insulin and glucagon were purchased from Litron Laboratories, Rochester, NY, USA. 


\section{Production of antisera}

Antisera to cIGF-II were prepared in female guinea pigs utilizing a modification of a procedure previously reported (McMurtry et al. 1994). Recombinantly derived cIGF-II was conjugated to keyhole limpet haemocyanin using conjugation kits supplied by Pierce Chemical Co., Rockford, IL, USA. Conjugation reactions and purifications of the conjugated peptide were carried out as recommended by the supplier. Initially, female guinea pigs were immunized against the conjugated protein $(100 \mu \mathrm{g}$ cIGF-II), emulsified in Freund's complete adjuvant. Freund's incomplete adjuvant was employed for four booster injections $(100 \mu \mathrm{g}$ peptide) at monthly intervals. Both adjuvants were purchased from Sigma Chemical Co., St Louis, MO, USA. Guinea pigs were bled 14-21 days after booster injections, and the sera harvested to test for the presence of anti-cIGF-II antibodies. Antiserum from one guinea pig (40A) was selected for further validation and characterization based on its antibody titre and high affinity for cIGF-II. Anti-guinea pig $\gamma$-globulin serum (secondary antibody) was prepared as previously described (McMurtry et al. 1994). The validation and characterization of the RIA were carried out based on the guidelines for hormone immunoassays suggested by Hafs et al. (1977).

\section{Radioiodination}

Iodination of cIGF-II was carried out as previously described (McMurtry et al. 1994) with minor modifications. Aliquots of $5 \mu \mathrm{g}$ cIGF-II were dissolved in $25 \mu \mathrm{l}$ sodium phosphate buffer $(500 \mathrm{mmol} / \mathrm{l}), \mathrm{pH} 7 \cdot 4$, lyophilized, and stored frozen $\left(-70{ }^{\circ} \mathrm{C}\right)$ in $1 \mathrm{ml}$ serum vials. No loss in iodination capability was noted after 1 year of storage. For radioiodination, the vial was thawed and $0.8 \mathrm{mCi}$ carrier-free $\mathrm{Na}^{125} \mathrm{I} \quad(100 \mathrm{mCi} / \mathrm{ml}$; Amersham Corp., Arlington Heights, IL, USA) added. Chloramine T $(5 \mu \mathrm{g})$ was added in $10 \mu \mathrm{l}$ sodium phosphate buffer $(50 \mathrm{mmol} / \mathrm{l}), \mathrm{pH} 7 \cdot 4$, and the reaction was stopped after $60 \mathrm{~s}$ by the addition of $20 \mu \mathrm{g}$ sodium metabisulphite (Fluka Chemical Corp., Ronkonhoma, NY, USA) in $20 \mu \mathrm{l}$ sodium phosphate buffer $(50 \mathrm{mmol} / \mathrm{l})$. Unreacted $\mathrm{Na}^{125} \mathrm{I}$ was separated from ${ }^{125}$ I-labelled cIGF-II by chromatography on Sephadex G-50 (Pharmacia, Piscataway, NJ, USA) $(0.7 \times 50 \mathrm{~cm}$ glass column; Kontes, Vineland, NJ, USA), pre-equilibrated with sodium phosphate buffer $(50 \mathrm{mmol} / \mathrm{l})$, $\mathrm{pH} 7 \cdot 4$, containing $0 \cdot 1 \% \quad(\mathrm{w} / \mathrm{v})$ BSA (RIA grade; Sigma Chemical Co.). cIGF-II was iodinated to a specific activity of $60 \mathrm{Ci} / \mathrm{g}$ by this method. After radioiodination, ${ }^{125}$ I-labelled cIGF-II was aliquotted and stored at $-70{ }^{\circ} \mathrm{C}$ for up to 2 months without any loss in immunoreactivity. Use of polypropylene vials and tubes (Sarstedt, Princeton, NJ, USA) minimized non-specific adherence of ${ }^{125}$ I-labelled cIGF-II.

\section{Assay buffers and conditions}

Sodium phosphate buffer $(30 \mathrm{mmol} / \mathrm{l} ; \mathrm{pH} 7 \cdot 5)$, containing $10 \mathrm{mmol} / 1$ EDTA (Sigma Chemical Co.), $0 \cdot 02 \%$ (w/v) protamine sulphate and $0 \cdot 02 \%(\mathrm{w} / \mathrm{v})$ sodium azide (Sigma Chemical Co.) was used for dilution of primary and secondary antibodies as well as for standard hormone. Standard hormone (cIGF-II) and tracer $\left({ }^{125}\right.$ I-labelled cIGF-II) were dissolved, diluted and stored in the phosphate buffer containing $0 \cdot 1 \%(\mathrm{w} / \mathrm{v})$ BSA. The RIA diluent was the above phosphate buffer containing $0.05 \%$ (v/v) Tween 20 (Sigma Chemical Co.).

To enhance the sensitivity of the RIA, the assay was conducted under non-equilibrium conditions. On day 1 , RIA diluent $(50 \mu \mathrm{l})$ plus $50 \mu \mathrm{l}$ sample acid/ethanol (A/E) extract or standard (cIGF-II) were added to RIA tubes containing $100 \mu \mathrm{l}$ primary antibody (1:3500 working dilution), vortex-mixed and incubated overnight at $4{ }^{\circ} \mathrm{C}$. On day $2,100 \mu \mathrm{l}$ tracer containing 6000 c.p.m. ${ }^{125} \mathrm{I}-$ Labelled cIGF-II was added to each tube, vortex-mixed and incubated overnight at $4{ }^{\circ} \mathrm{C}$. On day 3 , secondary antibody $(100 \mu \mathrm{l}$ of a 1:15 dilution of sheep anti-guinea pig $\gamma$-globulin) and carrier (100 $\mu$ l normal guinea pig serum diluted 1:200 in phosphate buffer) were added to each tube, vortex-mixed and incubated overnight at $4{ }^{\circ} \mathrm{C}$. On day 4, $1.5 \mathrm{ml}$ polyethylene glycol (PEG 6000; Fluka Chemical Corp.) at $2-5{ }^{\circ} \mathrm{C}$ was added to each tube, followed by vortex-mixing and centrifugation at $2000 \mathrm{~g}$ for $30 \mathrm{~min}$. The resulting supernatant was aspirated and the pellet counted in a $\gamma$-counter. All RIA data reductions were conducted using the log/logit transformation (Rodbard 1974). Intra- and interassay coefficients of variation were calculated as described by Abplanalp et al. (1977).

Plasma IGF-I concentrations were determined by homologous RIA for cIGF-I (McMurtry et al. 1994).

\section{A/E extraction of blood samples}

A/E extraction of blood samples was performed as previously described by McMurtry et al. (1994). To a $1.5 \mathrm{ml}$ Eppendorf Microfuge tube was added $40 \mu \mathrm{l}$ chicken or turkey plasma plus $10 \mu \mathrm{l}$ Dulbecco's PBS, pH 7·4 (Sigma Chemical Co.) followed by $500 \mu \mathrm{l}$ acid/ethanol $(12.5 \mathrm{ml} 2$ $\mathrm{mol} / \mathrm{l} \mathrm{HCl}+87 \cdot 5 \mathrm{ml}$ ethanol; $\mathrm{pH} \mathrm{3 \cdot 0)}$. The mixture was vortex-mixed and allowed to stand at room temperature for $30 \mathrm{~min}$ then neutralized by the addition of $250 \mu \mathrm{l}$ $855 \mathrm{mmol} / 1$ Tris base (Sigma Chemical Co.). The sample was then centrifuged at $2000 \mathrm{~g}$ for $10 \mathrm{~min}$ at $4{ }^{\circ} \mathrm{C}$. After centrifugation, a $50 \mu \mathrm{l}$ aliquot was removed for IGF-II determination. Alternatively, A/E extraction was performed using the cryoprecipitation method reported by Breier et al. (1991) as modified for chicken plasma (McMurtry et al. 1994).

\section{Gel chromatography}

The following experiments were carried out to assess the possible interference of IGF-binding proteins (IGFBPs) in 
the RIA. In the first experiment, $1 \mathrm{ml}$ chicken or turkey plasma was acidified ( $\mathrm{pH} \mathrm{3.0)}$ with an equal volume of $500 \mathrm{mmol} / \mathrm{l}$ acetic acid and incubated overnight at $4{ }^{\circ} \mathrm{C}$. The sample was then centrifuged and a $200 \mu$ aliquot chromatographed by fast performance liquid chromatography (FPLC) on a Superdex 75 HR 10/30 column (Pharmacia), pre-equilibrated with $500 \mathrm{mmol} / \mathrm{l}$ acetic acid. The column was eluted at a flow rate of $0.5 \mathrm{ml} / \mathrm{min}$ and $0.5 \mathrm{ml}$ fractions were collected. The fractions were dried under vacuum, reconstituted in $100 \mu \mathrm{l}$ assay buffer, and immunoassayed for IGF-II content. $M_{\mathrm{r}}$ markers obtained from Pharmacia, as well as ${ }^{125}$ I-labelled cIGF-II, were used for column standardization.

In the second experiment, the following samples $(200 \mu \mathrm{l})$ were chromatographed under neutral conditions: normal chicken plasma, A/E-extracted chicken plasma and cryoprecipitated A/E-extracted chicken plasma. Samples were chromatographed on an FPLC Superose 12 $(10 \times 300 \mathrm{~mm})$ column (Pharmacia), pre-equilibrated with a buffer containing sodium phosphate $(50 \mathrm{mmol} / \mathrm{l})$, $\mathrm{NaCl}(150 \mathrm{mmol} / \mathrm{l})$, sodium azide $(0.02 \%)$ and sodium heparin $(10 \mathrm{U} / \mathrm{ml})$ and adjusted to $\mathrm{pH} 7 \cdot 4$. The column was eluted at a flow rate of $0.5 \mathrm{ml} / \mathrm{min}$ and $0.5 \mathrm{ml}$ fractions were collected. The fractions were dried under vacuum, reconstituted in assay buffer, and immunoassayed for IGF-II content. $M_{\mathrm{r}}$ markers obtained from Pharmacia, as well as ${ }^{125}$ I-labelled cIGF-II, were used for column standardization.

\section{Animal studies}

All animal studies were conducted using research protocols approved by the Beltsville Area Animal Use Committee. For the chick embryo experiment, fertile chick eggs were obtained from Central Farms, Fayetteville, NC, USA. Fertile turkey eggs were obtained from British United Turkey, Harrisonburg, VA, USA. Fertile eggs were incubated under standard incubation conditions. Blood samples were collected from chick and turkey embryos as previously reported (McMurtry et al. 1989). For the growth studies, day-old male broiler chicks and male turkeys were purchased from Shaver Poultry Breeding Farms, Ltd, Cambridge, Ontario, Canada and British United Turkeys respectively. Both species were housed under standard growing conditions and provided standard starter and grower diets for the duration of the experiments. Blood samples were withdrawn from the brachial vein using EDTA-treated syringes (Sarstedt), and the plasma was harvested by centrifugation and stored at $-70{ }^{\circ} \mathrm{C}$ until analysed for IGF-II content.

To determine the effect of nutritional status on circulating IGF-II concentrations, the following experiments were conducted. The effect of nutrient deprivation on IGF-II was determined by subjecting 4-week-old male chicks to food withdrawal. Blood samples were taken at the following intervals: $24 \mathrm{~h}$ before food removal, at 24 and
$48 \mathrm{~h}$ after food deprivation, and $24 \mathrm{~h}$ after refeeding. In addition, the effect of dietary protein levels on blood IGF-II was determined by feeding 2 -week-old chicks either 12 or $21 \%$ crude protein for a 2 -week period as previously described (Rosebrough \& McMurtry 1993). Brachial vein blood samples were taken at the end of the feeding period.

It is well established that the IGFs are present in most tissues as well as in the general circulation (Daughaday \& Rotwein 1989). To determine whether the source of plasma and tissue trauma (decapitation) could possibly influence immunoassayable IGF-I and -II, the following experiment was conducted. Six-week-old male broiler chickens were fitted with an indwelling jugular vein cannula as previously described (McMurtry \& Brocht 1984). Simultaneous blood samples were withdrawn from a wing vein and cannula into EDTA-treated tubes (Sarstedt). Within $10 \mathrm{~s}$, the bird was decapitated and trunk blood collected into EDTA-treated conical centrifuge tubes. All samples were processed and assayed for IGF-I and -II content as described above.

\section{Statistics}

ANOVA was carried out using the statistical programs provided by STATSOFT, Tulsa, OK, USA.

\section{Results}

Four anti-cIGF-II sera were produced and tested for their suitability as a source of antibody for the homologous cIGF-II RIA (data not shown). The antiserum (40A) with highest titre was chosen for RIA development and provided the maximum sensitivity. The immunological properties of this antiserum in the homologous RIA are depicted in Fig. 1. Using recombinant cIGF-II as standard and tracer, the double-antibody immunoassay has a minimum detection limit of 78 pg per tube at $90 \%$ residual binding and an effective dose of 990 pg (Fig. 1). Recombinant human IGF-II cross-reacted approximately 5\% with the antiserum (data not shown). Furthermore, the antibody did not cross-react with cIGF-I or any of the other peptide hormones (chicken insulin and glucagon) tested at up to $2 \mu \mathrm{g}$ per tube (data not shown). Doseresponse curves of $\mathrm{A} / \mathrm{E}$-extracted chicken and turkey plasma (Fig. 1) were parallel to that of the cIGF-II standard. The recovery of added cIGF-II from chicken and turkey plasma after A/E extraction averaged 95.3 and $97.5 \%$ respectively (Table 1 ). No difference in recovery was observed whether the plasma sample was subjected to the standard A/E extraction or A/E followed by cryoprecipitation (Table 1). An average intra-assay coefficient of variation of $3 \cdot 25 \%$ was calculated from a group of chicken and turkey plasma samples $(n=25)$. An average interassay coefficient of variation of $12.5 \%$ was determined by 


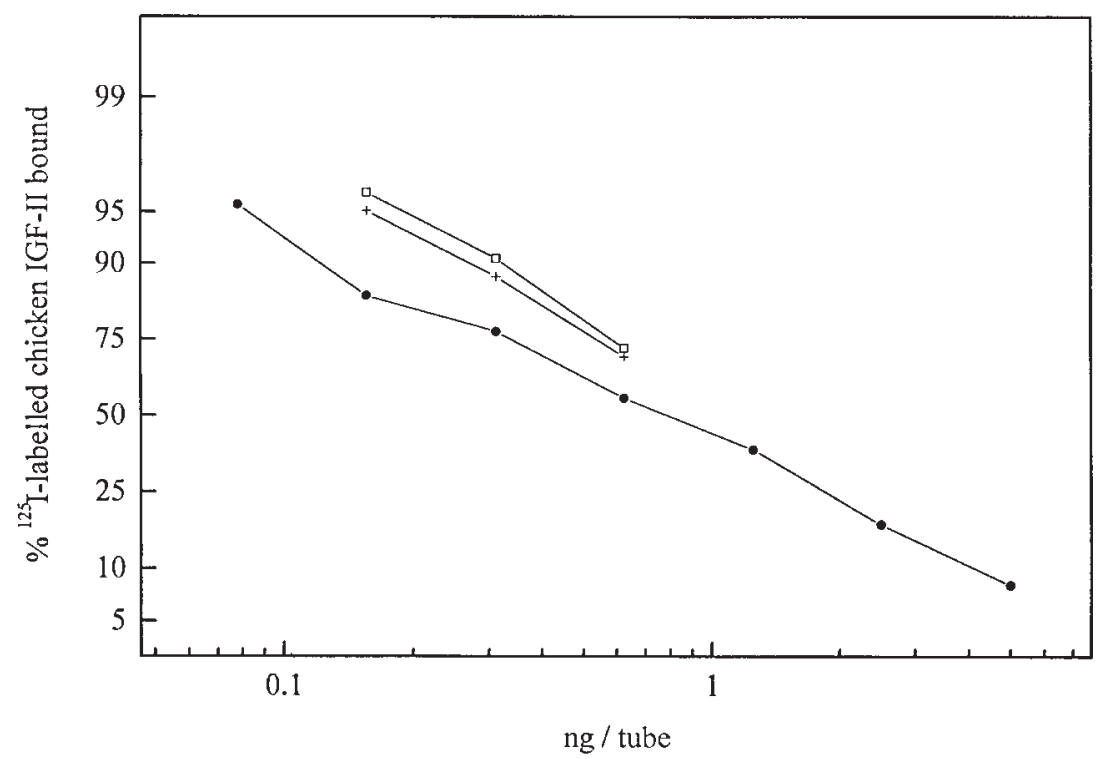

Figure 1 Competitive binding curves obtained with serial dilutions of recombinant cIGF-II $(\bullet)$ and serial dilutions of A/E-extracted chicken $(+)$ and turkey $(\square)$ plasma in an homologous RIA for cIGF-II. The RIA inhibition curves were plotted as percentage bound (logit scale) versus amount per tube (log scale).

Table 1 Recovery of cIGF-II from chicken and turkey plasma after A/E extraction or A/E extraction and cryoprecipitation (AEC). Values are means \pm S.E.M.

Chicken plasma

cIGF-II (pg/tube)
0
5
10
25

\begin{tabular}{lll}
\hline $\mathrm{A} / \mathrm{E}$ & & $\mathrm{AEC}$ \\
\cline { 1 - 1 } & & \\
\hline $41 \cdot 6 \pm 1 \cdot 7$ & & $42 \cdot 5 \pm 2 \cdot 2$ \\
$43 \cdot 5 \pm 2 \cdot 2$ & & $44 \cdot 9 \pm 1 \cdot 8$ \\
$49 \cdot 8 \pm 1 \cdot 3$ & & $50 \cdot 2 \pm 1 \cdot 0$ \\
$64 \cdot 1 \pm 0 \cdot 9$ & & $64 \cdot 1 \pm 1 \cdot 4$
\end{tabular}

\section{Turkey plasma}

\begin{tabular}{|c|c|}
\hline $\mathrm{A} / \mathrm{E}$ & $\mathrm{AEC}$ \\
\hline $35 \cdot 4 \pm 0.9$ & $33 \cdot 3 \pm 2 \cdot 6$ \\
\hline $37 \cdot 6 \pm 1 \cdot 2$ & $37.9 \pm 3.9$ \\
\hline $44 \cdot 8 \pm 1 \cdot 2$ & $43 \cdot 3 \pm 2 \cdot 0$ \\
\hline $58 \cdot 8 \pm 2 \cdot 4$ & $57 \cdot 0 \pm 3 \cdot 2$ \\
\hline
\end{tabular}

clGF-II dissolved in $5 \mu$ l saline was added in the above amounts to $35 \mu$ l chicken $(n=6)$ or turkey $(n=6)$ plasma pools, and subjected to either A/E or AEC extraction. Samples were assayed for IGF-II content as described in Materials and Methods. assaying this same group of samples in three separate assays (data not shown).

Measurement of IGF-II concentrations in mammalian plasma and sera is influenced by the binding proteins (IGFBPs) to which IGF-II is complexed. In order to characterize possible interference by the IGFBPs in the homologous RIA, chicken and turkey plasma were analysed by gel filtration chromatography under acid conditions ( $\mathrm{pH} 3 \cdot 0)$, and the fractions assayed for IGF-II (Fig. 2). No immunoreactivity was observed in the region $\left(M_{\mathrm{r}}=158000\right.$ to 43000$)$ in which IGFBP activity would be expected, because of competition for tracer binding (Fig. 2), while immunoreactivity of chicken and turkey plasma were eluted at the same position as the cIGF-II tracer. Furthermore, a similar result was obtained when chicken plasma was first extracted by either standard A/E extraction or cryoprecipitated $\mathrm{A} / \mathrm{E}$ extraction (data not shown), then chromatographed under neutral $\mathrm{pH}$ conditions (Fig. 3). Low levels of IGF-II immunoreactivity were observed in the normal chicken plasma sample (unextracted) in the $M_{\mathrm{r}}$ region in which IGFBPs may exist after neutral gel filtration. No difference in immunoreactive pattern was evident between chromatographed plasma obtained from chickens of 30 or 50 days of age. No evidence of any IGFBP activity was observed in the A/E-extracted samples. A similar result was observed when turkey plasma was chromatographed under neutral conditions (Fig. 4). The immunoreactive pattern was similar for 5- and 7-week-old turkey plasmas. This indicates that intact avian IGFBPs are not present in $\mathrm{A} / \mathrm{E}$ samples or do not interfere in the RIA after acid treatment.

The site from which whole blood was obtained for plasma harvest did not influence IGF-I or -II concentrations (Table 2). Growth factor levels were the same 


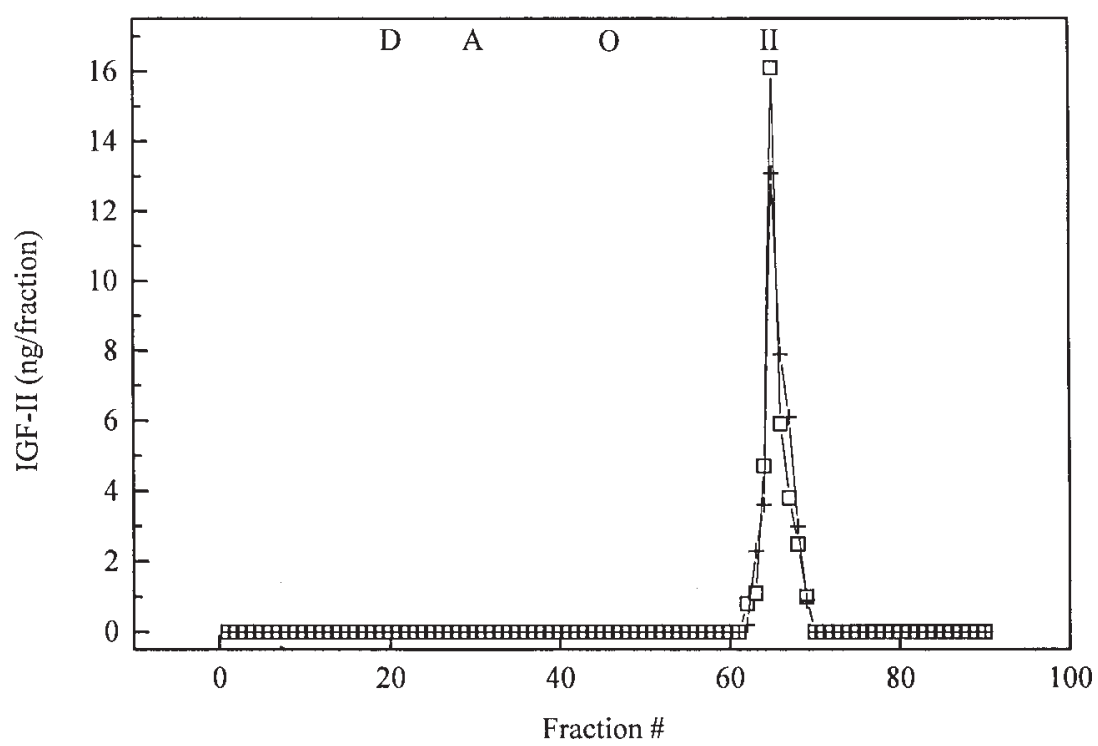

Figure 2 RIA of IGF-II after chromatography of turkey plasma ( $\square$ ) and chicken plasma (+) under acid conditions on a Superdex 75 HR 10/30 column. The column was calibrated using the following $M_{\mathrm{r}}$ markers: $\mathrm{D}=$ blue dextran (void volume); $\mathrm{A}=$ aldolase $\left(M_{\mathrm{r}}=158000\right)$; $\mathrm{O}=$ ovalbumin $\left(M_{\mathrm{r}}=43000\right)$; and $I I={ }^{125}$ I-labelled cIGF-II. Sample analysis was conducted as described in Materials and Methods. Data points represent the mean of three separate plasma samples.

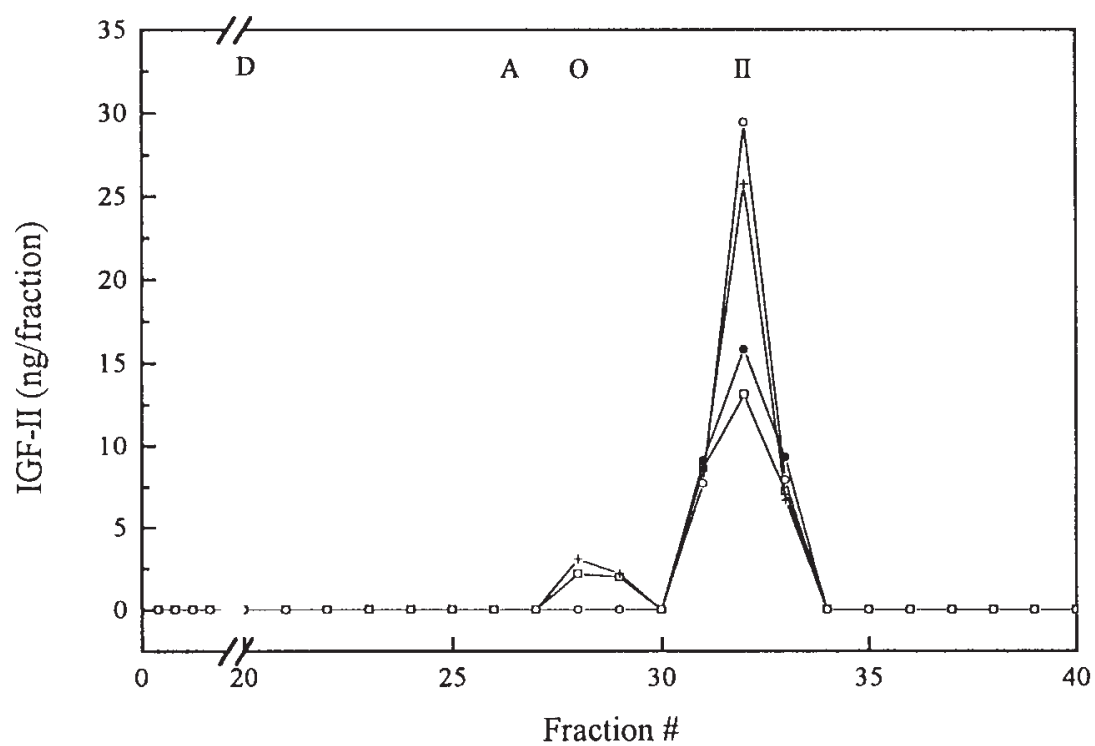

Figure 3 RIA of IGF-II in post-hatch chicken plasma after chromatography of day 30 chicken plasma $(\square)$, A/E-extracted day 30 chicken plasma $(\mathbf{O})$, day 50 chicken plasma (+) and A/E-extracted day 50 chicken plasma $(\bigcirc)$ under neutral conditions on a Superose-12 column $(10 \times 300 \mathrm{~mm})$. The column was calibrated using the following $M_{\mathrm{r}}$ markers: $\mathrm{D}=$ blue dextran (void volume); $A=$ aldolase $\left(M_{\mathrm{r}}=158000\right) ; \mathrm{O}=$ ovalbumin $\left(M_{\mathrm{r}}=43000\right) ;$ and $\|={ }^{125}$ I-labelled chicken IGF-II. Sample analysis was conducted as described in Materials and Methods. Data points represent the mean of three separate samples.

whether blood was obtained by venepuncture, decapitation or withdrawn from an indwelling cannula. It is evident that tissue trauma resulting from decapitation did not alter immunoassayable IGF.
A differential response in circulating IGF (I and II) levels to feeding a diet low in dietary protein $(12 \%$ crude protein) for a 2 -week period to male broiler chickens was noted (Table 3). Circulating plasma IGF-I concentrations 


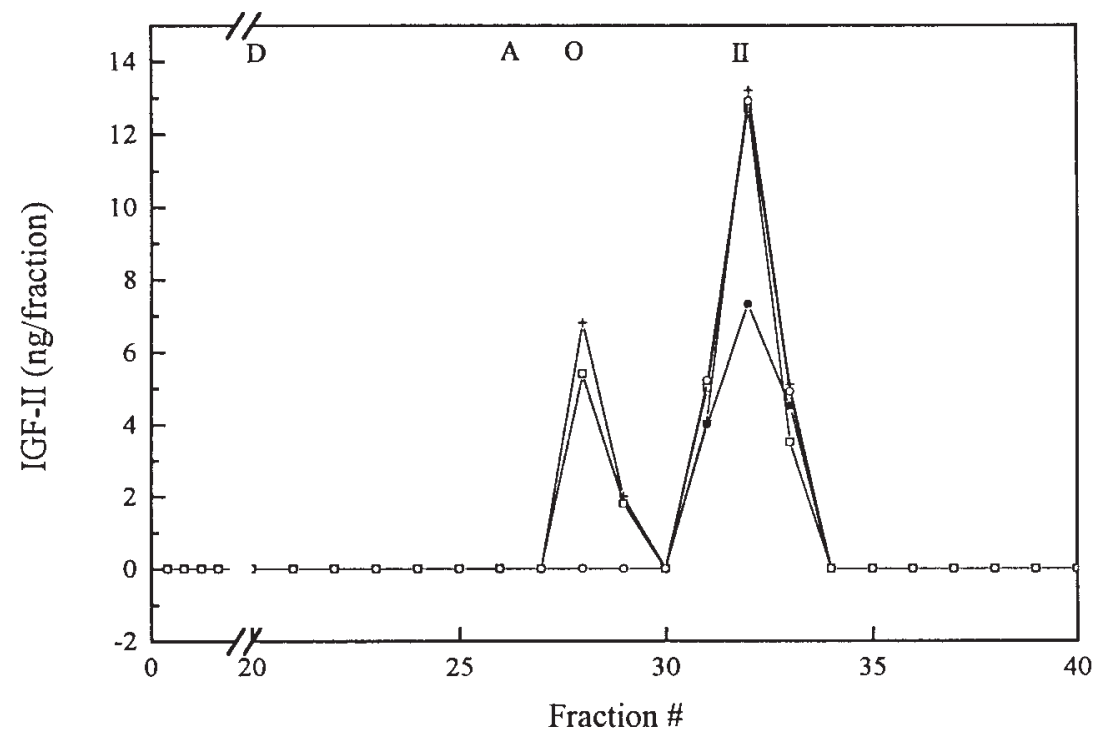

Figure 4 RIA of IGF-II in post-hatch turkey plasma after chromatography of 5-week turkey plasma $(\square)$, A/E-extracted 5-week turkey plasma $(\bullet), 7$-week turkey plasma $(+)$ and A/E-extracted 7-week turkey plasma $(\bigcirc)$ under neutral conditions on a Superose-12 column $(10 \times 300 \mathrm{~mm})$. The column was calibrated using the following $M_{\mathrm{r}}$ markers: $\mathrm{D}=$ blue dextran (void volume); $\mathrm{A}=$ aldolase $\left(M_{\mathrm{r}}=158000\right) ; \mathrm{O}=$ ovalbumin $\left(M_{\mathrm{r}}=43000\right)$; and $\|={ }^{125}$ I-labelled chicken IGF-II. Sample analysis was conducted as described in Materials and Methods. Data points represent the mean of three separate samples.

were twofold lower in chicks fed the low-protein diet $(26.5 \mathrm{ng} / \mathrm{ml})$ compared with that in birds fed $21 \%$ crude protein $(50.5 \mathrm{ng} / \mathrm{ml})$. Plasma IGF-II concentrations were unaffected by dietary protein (Table 3 ). The effects of food

Table 2 Comparison of plasma source of immunoreactive IGF-I and -II. Values represent means \pm S.E.M. ( $n=8$ /group)

\begin{tabular}{llll} 
& $\begin{array}{l}\text { IGF-I } \\
(\mathrm{ng} / \mathrm{ml})\end{array}$ & & $\begin{array}{l}\text { IGF-II } \\
(\mathrm{ng} / \mathrm{ml})\end{array}$ \\
\cline { 2 - 2 } $\begin{array}{lll}\text { Plasma source } \\
\text { Venepuncture }\end{array}$ & $12 \cdot 7 \pm 0 \cdot 6^{\mathrm{a}}$ & & $24 \cdot 7 \pm 1 \cdot 5^{\mathrm{a}}$ \\
$\begin{array}{l}\text { Jugular cannula } \\
\text { Trunk }\end{array}$ & $12 \cdot 0 \pm 1 \cdot 6^{\mathrm{a}}$ & & $24 \cdot 2 \pm 1 \cdot 0^{\mathrm{a}}$ \\
& $12 \cdot 4 \pm 0 \cdot 9^{\mathrm{a}}$ & & $26 \cdot 1 \pm 3 \cdot 2^{\mathrm{a}}$ \\
& &
\end{tabular}

Values in a column with common superscripts are not significantly different, $P>0 \cdot 05$.

Table 3 Effect of dietary protein on plasma IGF-I and -II. Values represent means \pm S.E.M. $(n=12$ /group $)$

\begin{tabular}{llll} 
& $\begin{array}{l}\text { IGF-I } \\
(\mathrm{ng} / \mathrm{ml})\end{array}$ & & $\begin{array}{l}\text { IGF-II } \\
(\mathrm{ng} / \mathrm{ml})\end{array}$ \\
\cline { 2 - 2 } $\begin{array}{l}\text { Protein content } \\
\text { of diet }(\%)\end{array}$ & & \\
12 & $26 \cdot 5 \pm 5 \cdot 5^{\mathrm{a}}$ & & $53 \cdot 1 \pm 2 \cdot 8^{\mathrm{a}}$ \\
21 & $50 \cdot 5 \pm 6 \cdot 4^{\mathrm{b}}$ & & $52 \cdot 2 \pm 1 \cdot 5^{\mathrm{a}}$
\end{tabular}

Values in a column with different superscripts are significantly different, $P<0 \cdot 05$. withdrawal and subsequent refeeding on circulating IGF-I and -II are shown in Table 4. Plasma IGF-I concentrations were significantly $(P<0 \cdot 05)$ decreased after $24 \mathrm{~h}$ of food deprivation, whereas IGF-II levels were dramatically elevated $(P<0 \cdot 05)$. This general pattern was still evident after $48 \mathrm{~h}$ of food withdrawal, although IGF-II concentrations were lower $(74.6 \mathrm{ng} / \mathrm{ml})$ than at $24 \mathrm{~h}(93.8 \mathrm{ng} /$ $\mathrm{ml})$. IGF-I levels remained suppressed at $48 \mathrm{~h}$ after the initiation of food withdrawal. By $24 \mathrm{~h}$ after refeeding, plasma IGF-II concentrations had returned to those in the fed state, whereas IGF-I levels remained depressed (Table 4).

During chick embryo incubation very dramatic differences between plasma IGF-I and -II in pattern and absolute levels were observed (Fig. 5). Plasma IGF-II levels were tenfold higher than IGF-I levels in the samples obtained on days 13 to 21 of incubation. During the post-hatch growth period, plasma IGF-II declined from $47 \mathrm{ng} / \mathrm{ml}$ on day 5 to less than $35 \mathrm{ng} / \mathrm{ml}$ on day 20 , and remained around this average concentration for the sampling period. Conversely, plasma IGF-I concentrations averaged less than $15 \mathrm{ng} / \mathrm{ml}$ on day 5 , and increased, reaching levels higher than $35 \mathrm{ng} / \mathrm{ml}$ on day 40 , then rapidly declined to an average concentration of $20 \mathrm{ng} / \mathrm{ml}$ on day 50.

Plasma IGF-I and -II concentrations during turkey embryo development are shown in Fig. 6. In early development (days 10 to 16), plasma IGF-II ranged from 
Table 4 Effect of food withdrawal and refeeding on plasma IGF-I and -II in the male broiler chicken (30 days of age). Values represent means \pm S.E.M. $(n=8)$

\begin{tabular}{|c|c|c|c|c|}
\hline & \multicolumn{2}{|c|}{ IGF-I (ng/ml) } & \multicolumn{2}{|c|}{ IGF-II (ng/ml) } \\
\hline & Control & Treated & Control & Treated \\
\hline Fed & $44.9 \pm 1.9^{a}$ & $43 \cdot 5 \pm 2 \cdot 7^{a}$ & $\overline{57 \cdot 3 \pm 3 \cdot 0^{a}}$ & $\overline{56 \cdot 8 \pm 2 \cdot 8^{a}}$ \\
\hline Fasted, 24 h & $45 \cdot 6 \pm 2 \cdot 1^{a}$ & $33 \cdot 6 \pm 2 \cdot 2^{b}$ & $55 \cdot 9 \pm 2 \cdot 5^{a}$ & $93 \cdot 8 \pm 5 \cdot 9^{b}$ \\
\hline Fasted, $48 \mathrm{~h}$ & $46 \cdot 7 \pm 1 \cdot 3^{a}$ & $30 \cdot 3 \pm 1 \cdot 7^{b}$ & $58 \cdot 4 \pm 3 \cdot 3^{a}$ & $74 \cdot 6 \pm 6 \cdot 6^{c}$ \\
\hline Refed, 24 h & $44 \cdot 6 \pm 2 \cdot 6^{\mathrm{a}}$ & $33 \cdot 9 \pm 2 \cdot 8^{b}$ & $53 \cdot 9 \pm 4 \cdot 2^{a}$ & $48 \cdot 4 \pm 3 \cdot 3^{a}$ \\
\hline
\end{tabular}

Values in the same column with different superscripts are significantly different, $P<0 \cdot 05$.

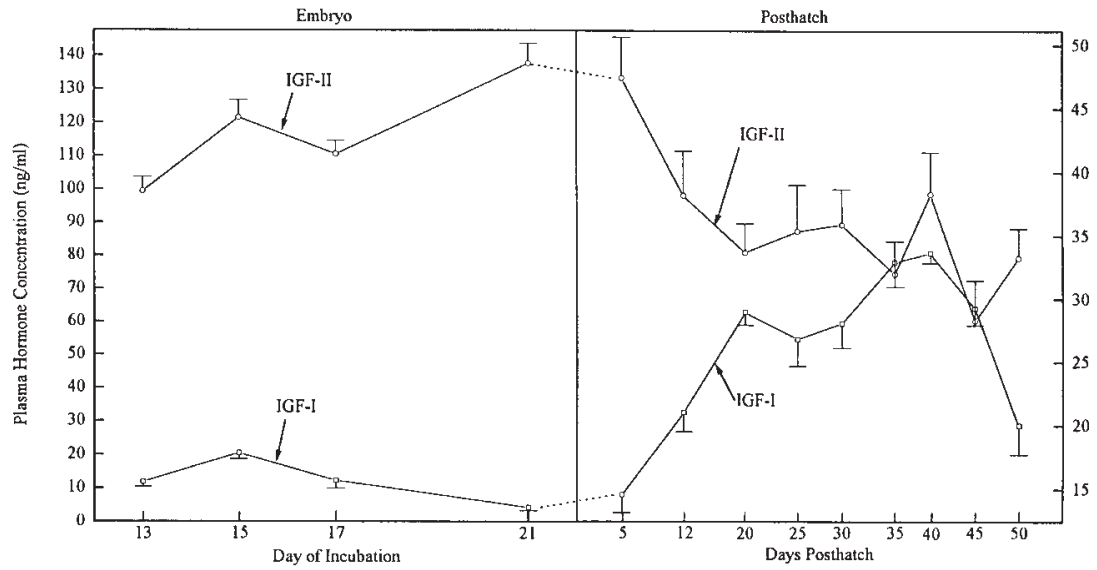

Figure 5 Plasma IGF-I $(\square)$ and -II $(\bigcirc)$ concentrations during embryonic development and post-hatch growth in broiler chickens. Embryo samples ( $n=6 /$ day of incubation) were collected from unsexed embryos, whereas samples were obtained from male chickens during the post-hatch period $(n=8 /$ day). Values are mean \pm S.E.M.

20 to $35 \mathrm{ng} / \mathrm{ml}$. Between days 16 and 18 , they more than doubled $(67 \mathrm{ng} / \mathrm{ml})$. During the later stages of incubation, plasma IGF-II concentrations remained elevated (65$90 \mathrm{ng} / \mathrm{ml})$. At hatching, IGF-II levels had declined to less than $40 \mathrm{ng} / \mathrm{ml}$. Throughout incubation (except for day 14) circulating IGF-I levels were significantly $(P<0 \cdot 05)$ lower than IGF-II concentrations (Fig. 6). A steady increase in circulating IGF-I was observed (days 10 to 18), peaking on day 18 , and remaining high (days 18 to 26) for the remainder of the incubation. At hatching (day 28), circulating IGF-I was similar to that in early incubation.

In the early post-hatch growth period of the male turkey (weeks 1 to 2), plasma IGF-II levels were higher than IGF-I levels (Fig. 6). From week 3 to 7, IGF-I and -II concentrations were essentially similar. From week 8 to 20, IGF-II ranged between 25 and $40 \mathrm{ng} / \mathrm{ml}$, while IGF-I concentrations averaged between 8 and $20 \mathrm{ng} / \mathrm{ml}$ (Fig. 6).

\section{Discussion}

The roles of the IGFs in avian growth and development are not as well understood as in mammals. In addition, much more is known about the function of IGF-I than IGF-II in birds (McMurtry et al. 1997). In part, this is due to the lack of adequate amounts of chicken IGF-II available for biological studies and immunoassay development. Recently, the recombinant production of cIGF-II has been reported (Upton et al. 1995). In the present study, we report the development of a homologous RIA for cIGF-II and its application to monitoring plasma IGF-II concentrations during embryo development and posthatch growth in the chicken and turkey. For comparative purposes, IGF-I levels were also determined.

It has been previously reported that blood and tissue IGF-I in chickens may be underestimated when mammalian RIA reagents are used (McMurtry et al. 1994). A similar situation may exist for the determination of IGF-II. Utilizing homologous RIA reagents, we have observed that, in general, circulating IGF-II concentrations are twoto three-fold higher than previously reported for the chick embryo and during post-hatch growth. This may be due to strain differences between chickens (Kita et al. 1996) or it may reflect the use of homologous RIA reagents rather than heterologous reagents (Huybrechts et al. 1989, Scanes et al. 1989). 


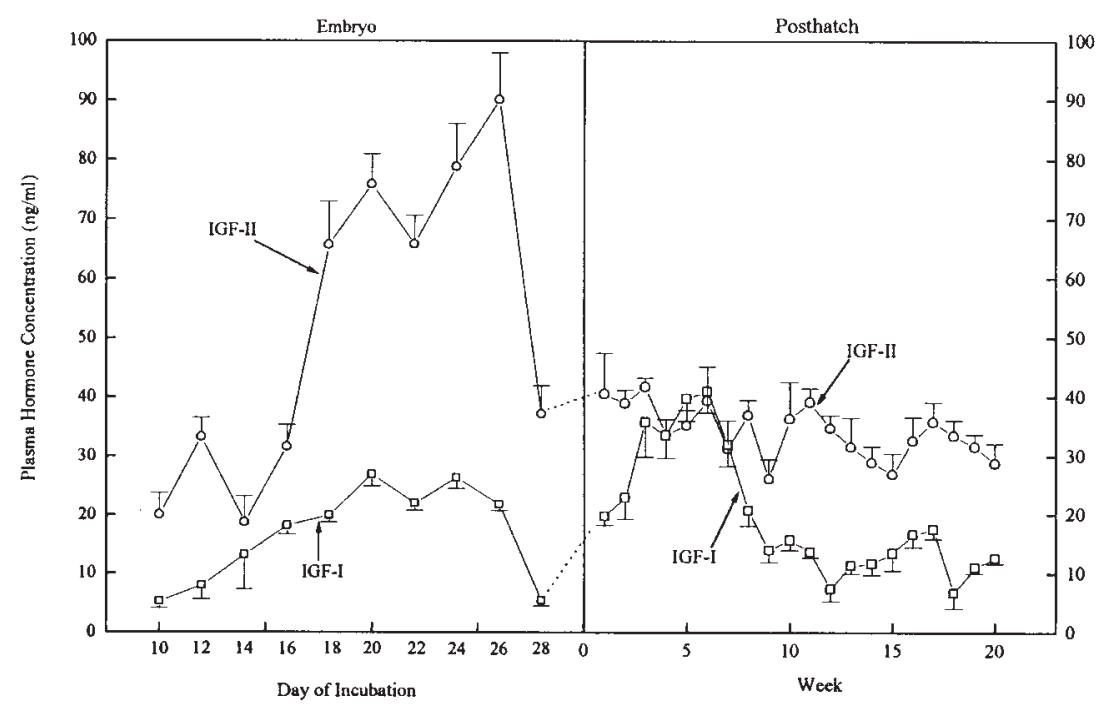

Figure 6 Plasma IGF-I $(\square)$ and -II $(\bigcirc)$ concentrations during embryonic development and post-hatch growth in turkeys. Embryo samples ( $n=8 /$ day of incubation) were collected from unsexed embryos, whereas samples were obtained from male turkeys during the post-hatch period $(n=8 /$ day). Values are mean \pm S.E.M.

It is well documented that in mammals (Daughaday \& Rotwein 1989) and birds (McMurtry et al. 1994, 1996a, Rosselot et al. 1995, McMurtry \& Brocht 1997) significant amounts of IGFs, as well as their binding proteins, are synthesized in most tissues. It was hypothesized that tissue damage caused by decapitation may alter growth factor concentrations in plasma compared with those found when whole blood is obtained by other methods. The site from and method by which whole blood was obtained for plasma harvest did not influence IGF-I or -II concentrations. Growth factor levels were the same whether blood was obtained by venepuncture, decapitation or withdrawn via a jugular cannula.

It is apparent that plasma concentrations of IGF-II vary with the physiological age and state of the bird. In the developing chick embryo, plasma IGF-II levels were elevated throughout incubation, and were noted to be tenfold higher than IGF-I levels. Huybrechts et al. (1989) reported that IGF-II levels were two- to three-fold higher than IGF-I levels during chick embryo development. The higher IGF-II concentrations observed in our study most likely reflect differences in the RIA reagents utilized in the respective assays. The pattern of circulating IGF-I in the chick embryo in our experiment was similar to that previously reported (Robcis et al. 1991). In addition, no mid-incubation peak in plasma IGF-II was observed, unlike circulating IGF-I (Robcis et al. 1991).

Plasma IGF-II levels have not been previously reported for either the turkey embryo or during the post-hatch growth period. Somewhat different patterns of circulating IGF-II concentrations were observed in the developing turkey and chick embryo. Throughout incubation, IGF-II concentrations were higher than those of IGF-I in the turkey embryo. A dramatic increase in IGF-II occurred between days 16 and 18 of incubation, with levels peaking on day 26 , followed by a precipitous decline at hatching (day 28). The pattern of circulating IGF-I was similar to that previously reported for the incubating turkey embryo (McMurtry et al. 1996b). Regardless of the pattern of growth factor levels during incubation of the turkey and chick embryo, it is evident that there are differences in the mechanisms controlling the synthesis and release of IGF-II compared with IGF-I. Furthermore, the control mechanisms for both IGF peptides remain an enigma, as neither growth factor is significantly influenced by growth hormone, since plasma growth hormone is not detectable until late incubation in both the chick (Porter et al. 1995) and turkey (McMurtry et al. 1990) embryo. It is obvious that other factors regulate IGF production during avian incubation and remain to be identified.

The elevated levels of IGF-II during turkey and chick embryonic development suggest that it is important in embryogenesis; also IGF-II is considered to be important in mammalian fetal development (Stewart \& Rotwein 1996). IGF-II gene expression has been evaluated in the chick embryo, with transcripts being detected in eye, heart and developing limb bud of 4-day-old chick embryos (Engstrom et al. 1987), as well as in differentiating turkey satellite cells (Ernst et al. 1996). The presence of an array of both sense and antisense IGF-II transcripts in stage 22 and stage 36 chick embryos has been reported (Taylor et al. 1991). Several functions have been ascribed to IGF-II during avian embryogenesis, ranging from increasing 
proliferation of various embryo-derived cell types, increasing cartilage growth and thymidine uptake, and increasing amino acid and glucose uptake by hepatocytes (McMurtry et al. 1997).

Similar to that observed during chick and turkey embryo incubation, plasma IGF-II levels during the posthatch growth period of both species varied depending on age and species. In the chicken, a precipitous fall occurred in the neonatal period, declining from over $130 \mathrm{ng} / \mathrm{ml}$ at hatching (day 21) to concentrations of less than $50 \mathrm{ng} / \mathrm{ml}$ by day 5 after hatching. Plasma IGF-II levels were noted to decline throughout the remaining sampling period (days 5 to 50 after hatching). In this study, circulating IGF-I was observed to be low during the first 2-3 weeks of age, when, as a percentage of body weight, the most rapid gains in body weight occur. Levels increased with age, plateauing at 40 days of age, and eventually declined to concentrations observed early in life. This pattern of circulating IGF-I is similar to that previously reported (Goddard et al. 1988, Ballard et al. 1990, Johnson et al. 1990, McGuinness \& Cogburn 1990).

In the growing male turkey, plasma IGF-II concentrations were fairly uniform throughout the growth period, whereas IGF-I levels declined during the later two-thirds of post-hatch growth. Although information is limited, it is not likely that IGF-II influences growth rate per se in domestic fowl. Scanes et al. (1989) have reported that plasma IGF-II concentrations are unrelated to growth rate in either dwarf or high growth rate lines of chickens. Furthermore, exogenous IGF-II administration to broiler chickens has no effect on overall somatic growth (Spencer et al. 1996). However, there is evidence that IGF-II may be involved in some aspect of fat metabolism as the same authors noted that the size of the abdominal fat pad was increased, whereas passive immunization against IGF-II decreased abdominal fat content (Spencer et al. 1995, 1997). The aspect of lipid metabolism in birds regulated in part by IGF-II awaits further study.

Interactions between the plane of nutrition and IGF-I in chickens are well documented (Vasilatos-Younken \& Scanes 1991). In general, fasting depresses circulating IGF-I, and refeeding returns levels to near pre-fasting values (Morishita et al. 1993). Our results confirm this observation. It has also been reported that a complete return to normal IGF-I occurs after restricted feeding of broiler chicks (Kita et al. 1996). The same authors have reported that plasma IGF-II is unaffected by nutrient restriction, whereas our results show that blood IGF-II concentrations are dramatically increased after food withdrawal, and return to normal levels after refeeding. In summary, our results and those previously reported suggest that IGF-II responds differentially to the level of nutrient deprivation (food withdrawal vs restriction) in chickens.

The results reported here confirm the influence of dietary protein on plasma IGF-I (Rosebrough et al. 1992, Rosebrough \& McMurtry 1993) and IGF-II (Kita et al.
1996) in chickens. Consumption of large calorie-toprotein ratio diets depresses plasma IGF-I, with no change in circulating IGF-II.

The presence of IGFBPs in chicken sera (Armstrong et al. 1989, Francis et al. 1990, Schoen et al. 1992, McMurtry et al. 1996a) and turkey sera (McMurtry et al. $1996 b)$ is well established. Whether avian IGFBPs are similar in structure and function to those in mammals is unresolved. It is widely appreciated that dissociation and removal of IGFBPs from blood samples by A/E extraction or acid gel chromatography is necessary before samples can be immunoassayed (Breier et al. 1991). Furthermore, it has been documented that chicken and turkey sera contain an IGFBP-like protein that is unique in that it preferentially binds IGF-II over IGF-I (McMurtry et al. 1996a, $b$ respectively). In this study parallelism and quantitative recovery of IGF-II was demonstrated in A/E-extracted plasma samples. These observations are indicative of an absence of interference by IGFBPs in the assay. Furthermore, the RIA results after neutral chromatography of A/Eextracted samples indicate that this method is effective in eliminating IGFBP interference when avian blood samples are immunoassayed. Others have reported similar results in that acid/ethanol appears to be efficient in eliminating IGFBP interference in the RIA (Ballard et al. 1990, McGuinness \& Cogburn 1990).

Even though turkey IGF-II has not been purified and sequenced and its DNA has not been sequenced, one can speculate that chicken and turkey IGF-II are structurally identical, since chicken and turkey insulin (Simon 1989) and chicken and turkey glucagon (Ferriera et al. 1991) are structurally identical. Therefore the use of recombinant cIGF-II and anti-cIGF-II antibody to monitor turkey IGF-II may more accurately reflect actual IGF-II immunoactivity than if a mammalian IGF-II sequence is used in the RIA.

A key distinction for the role of IGF-II in birds at all stages of development compared with mammals is the absence of an IGF-II-binding site on the cationindependent mannose 6-phosphate receptor in birds (Zhou et al. 1995). A variety of studies including genetic deletion models suggest a role for this receptor in controlling the growth factor action of IGF-II by sponsoring its internalization and degradation (Stewart \& Rotwein 1996). The interaction between IGF-II, the type I IGF receptor (an as yet uncharacterized IGF-II-binding species (McMurtry et al. 1997)), and presumably the insulin receptor will need to be investigated to provide an understanding of the role of IGF-II in growth and metabolism in birds.

\section{Acknowledgements}

Mention of a trade name, proprietary product, or specific equipment does not constitute a guarantee or warranty by 
USDA and does not imply its approval to the exclusion of other suitable products. The technical support of S Lutz and $\mathrm{W}$ Smoot is greatly appreciated.

\section{References}

Abplanalp J, Livingston L, Rose R \& Sandmisch D 1977 Cortisol and growth hormone responses to psychological stress during the menstrual cycle. Psychosomatic Medicine 39 158-177.

Armstrong DG, McKay CO, Morrell DJ \& Goddard C 1989 Insulin-like growth factor-I binding proteins in serum from the domestic fowl. Journal of Endocrinology 120 373-378.

Ballard F, Johnson R, Owens P, Francis G, Upton F, McMurtry J \& Wallace J 1990 Chicken insulin-like growth factor-I: amino acid sequence, radioimmunoassay, and plasma levels between strains and during growth. General and Comparative Endocrinology 79 459-468.

Breier B, Gallaher B \& Gluckman P 1991 Radioimmunoassay for insulin-like growth factor-I: solutions to some potential problems and pitfalls. Journal of Endocrinology 128 347-357.

Buonomo FC 1989 Determination of circulating insulin-like growth factor-II (IGF-II) in chickens. Poultry Science 68 (Suppl. 1) 20 (Abstract).

Daughaday W \& Rotwein P 1989 Insulin-like growth factors I and II. Peptide, messenger ribonucleic acid and gene structures, serum, and tissue concentrations. Endocrine Reviews 10 68-91.

Engstrom W, Bell KM \& Schofield PN 1987 Expression of the insulin like growth factor IGF-II gene in the developing chick limb. Cell Biology International Reports 11 415-421.

Ernst CW, McFarland DC \& White ME 1996 Expression of insulin-like growth factor II (IGF-II), IGF binding protein-2 and myogenin during differentiation of myogenic satellite cells derived from the turkey. Differentiation 61 25-33.

Ferreira A, Litthauer D, Saayman H, Oelofsen W, Crabb J \& Lazure C 1991 Purification and primary structure of glucagon ostrich pancreas splenic lobes. International Journal of Peptide and Protein Research 38 90-95.

Francis G, McMurtry J, Johnson R \& Ballard F 1990 Plasma clearance of chicken and human insulin-like growth factor-I and their association with circulating binding proteins in chickens. Journal of Endocrinology 124 361-370.

Goddard C, Wilkie R \& Dunn I 1988 The relationship between insulin-like growth factor-I, growth hormone, thyroid hormones and insulin in chickens selected for growth. Domestic Animal Endocrinology 5 165-176.

Hafs H, Niswender G, Malven P, Kaltenbach C, Zimbelman R \& Condon R 1977 Guidelines for hormone radioimmunoassay. Journal of Animal Science 45 927-929.

Huybrechts LM, Michielsen R, Darras VM, Buonomo FC, Kuhn ER \& Decuypere E 1989 Effect of the sex-linked dwarf gene on thyrotrophic and somatotrophic axes in the chick embryo. Reproduction Nutrition Development 29 219-226.

Johnson R, McMurtry J \& Ballard F 1990 Ontogeny and secretory patterns of plasma insulin-like growth factor-I concentrations in meat-type chickens. Journal of Endocrinology 124 81-87.

Jones JI \& Clemmons DR 1995 Insulin-like growth factors and their binding proteins: biological actions. Endocrine Reviews 16 3-34.

Kita K, Tomas FM, Owens PC, Knowles SE, Forbes BE, Upton Z, Hughes R \& Ballard FJ 1996 Influence of nutrition on hepatic IGF-I mRNA levels and plasma concentrations of IGF-I and IGF-II in meat-type chickens. Journal of Endocrinology 149 181-190.

McGuinness M \& Cogburn L 1990 Measurement of developmental changes in plasma insulin-like growth factor-I levels of broiler chickens by radioreceptor assay and radioimmunoassay. General and Comparative Endocrinology 79 446-458.

McMurtry JP \& Brocht D 1984 A surgical technique for serial blood sampling or continuous infusion of adult turkey hens. Poultry Science 63 1661-1663.
McMurtry JP \& Brocht DM 1997 Developmental changes in embryonic and extra-embryonic insulin-like growth factor-I tissue concentrations in the turkey embryo. Poultry Science 76 894-900.

McMurtry J, Richards M, Rosebrough R \& Steele N 1989 A diabetic-like condition of turkey embryos maintained in shell-less culture. Proceedings of Society for Experimental Biology and Medicine 190 324-329.

McMurtry JP, Richards MP, Kahl S \& Vasilatos-Younken R 1990 Pituitary, thyroid and insulin-like growth factor-I and -II status in turkey embryos maintained in shell-less culture. Poultry Science 69 (Suppl. 1) 91.

McMurtry JP, Francis GL, Upton FZ, Rosselot G \& Brocht DM 1994 Developmental changes in chicken and turkey insulin-like growth factor-I (IGF-I) studied with a homologous radioimmunoassay for chicken IGF-I. Journal of Endocrinology 142 225-234.

McMurtry JP, Francis GL, Upton Z, Walton PE, Rosselot G, Caperna TJ \& Brocht DM 1996a Plasma clearance and tissue distribution of labelled chicken and human IGF-I and IGF-II in the chicken. Journal of Endocrinology 150 149-160.

McMurtry JP, Richards MP, Brocht DM, Schoen T \& Waldbillig R 19966 Developmental changes in serum insulin-like growth factor-I and insulin-like growth factor binding proteins in the turkey embryo. Poultry Science 75 563-569.

McMurtry JP, Francis GL \& Upton Z 1997 Insulin-like growth factors in poultry. Domestic Animal Endocrinology 14 199-229.

Morishita D, Sasaki K, Wakita M \& Hoshino S 1993 Effect of fasting on serum insulin-like growth factor-I (IGF-I) levels and IGF-I-binding activity in cockerels. Journal of Endocrinology 139 363-370.

Porter TE, Couger GS \& Morpurgo B 1995 Evidence that somatotroph differentiation during chicken embryonic development is stimulated by a blood-borne signal. Endocrinology 136 3721-3728.

Robcis H, Caldes T \& DePablo F 1991 Insulin-like growth factor-I serum levels show a midembryogenesis peak in chicken that is absent in growth-retarded embryos culture ex ovo. Endocrinology 128 1895-1901.

Rodbard D 1974 Statistical quality control and routine data processing for radioimmunoassay and immunoradiometric assays. Clinical Chemistry 20 1255-1270.

Rosebrough RW \& McMurtry JP 1993 Protein and energy relationship in the broiler chicken. II. Effects of protein quantity and quality on metabolism. British Journal of Nutrition 70 667-678.

Rosebrough RW, McMurtry JP \& Vasilatos-Younken R 1992 Metabolic and hormonal effects of feeding chickens thyroxine and diets containing varied calorie to protein ratios. Nutrition Research 12 $77-87$.

Rosselot G, McMurtry JP, Vasilatos-Younken R \& Czerwinski S 1995 Effect of exogenous chicken growth hormone $(\mathrm{cGH})$ administration on insulin-like growth factor-I (IGF-I) gene expression in domestic fowl. Molecular and Cellular Endocrinology 114 157-166.

Rotwein P 1991 Structure, evolution, expression and regulation of insulin-like growth factors I and II. Growth Factors 5 3-18.

Scanes CG, Dunnington EA, Buonomo FC, Donoghue DJ \& Siegel PB 1989 Plasma concentrations of insulin like growth factors (IGF-) I and IGF-II in dwarf and normal chickens of high and low weight selected lines. Growth, Development and Aging 53 151-157.

Schoen T, Beebe D, Clemmons D, Chader G \& Waldbillig R 1992 Local synthesis and developmental regulation of avian vitreal insulin-like growth factor-binding proteins: a model for independent regulation in extravascular and vascular compartments. Endocrinology $1312846-2854$.

Simon J 1989 Chicken as a useful species for the comprehension of insulin action. Critical Reviews in Poultry Biology 2 121-148.

Spencer GSG, Decuypere E, Buyse J, Hodgkinson SC, Bass JJ \& Zeman M 1995 Passive immunization of insulin-like growth factor (IGF)-I and of IGF-1 and IGF-2 in chickens. Comparative Biochemistry and Physiology 110C 29-33. 
Spencer GSG, Decuypere E, Buyse J \& Zeman M 1996 Effect of recombinant human insulin-like growth factor-II on weight gain and body composition of broiler chickens. Poultry Science $\mathbf{7 5}$ 388-392.

Spencer GSG, Decuypere E, Buyse J, Lamosova D, Hodgkinson SC, Bass JJ \& Zeman M 1997 Growth and carcass composition in broiler-type chickens following passive immunization of insulin-like growth factor-2 (IGF-2) between 2 and 4 weeks of age. Comparative Biochemistry and Physiology 116C 239-243.

Stewart CEH \& Rotwein P 1996 Growth, differentiation, and survival: multiple physiological functions for insulin-like growth factors. Physiological Reviews 76 1005-1026.

Taylor ER, Seleiro EAP \& Brickell PM 1991 Identification of antisense transcripts of the chicken insulin-like growth factor-II gene. Journal of Molecular Endocrinology 7 145-154.
Upton Z, Francis GL, Kita K, Wallace JC \& Ballard FJ 1995 Production and characterization of recombinant chicken insulin-like growth factor-II from Escherichia coli. Journal of Molecular Endocrinology 14 79-90.

Vasilatos-Younken R \& Scanes CG 1991 Growth hormone and insulin-like growth factors in poultry growth: required, optimal, or ineffective? Poultry Science 70 1764-1780.

Zhou M, Ma Z \& Sly WS 1995 Cloning and expression of the cDNA of chicken cation-independent mannose-6-phosphate receptor. Proceedings of the National Academy of Sciences of the USA 92 9762-9766.

Received 10 September 1997 Accepted 9 January 1998 